\title{
Provincia ludaea: Eliana, Masada, Aelia Capitolina
}

\author{
Lynn LiCalsi \\ Fairview High School, USA
}

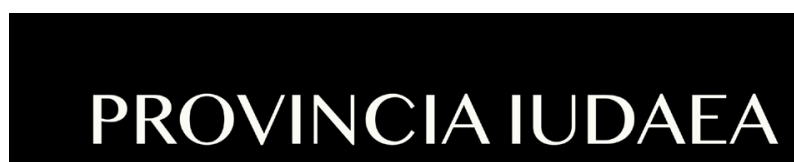

\section{ELIANA, MASADA, AELIA CAPITOLINA}

Historically based Stories for

Beginning and Intermediate Latin Students

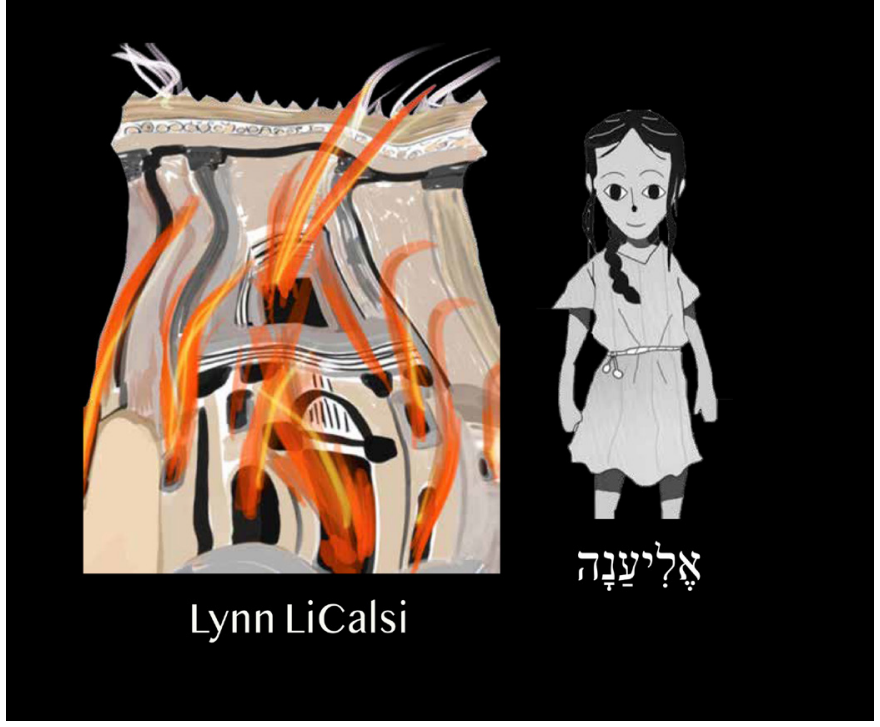

Figure 1. Cover: Provincia ludaea

Provincia Iudaea is a supplementary reader for beginning and intermediate Latin students. It includes three stories set in firstcentury Judaea. The stories explain the confrontation between Romans and Jews at this time. The first story unfolds through the eyes of the main character, a young Jewish girl named Eliana. After the destruction of the Second Temple in $70 \mathrm{CE}$, Eliana and her mother escape to Masada. Many years later, $132 \mathrm{CE}$, another character, Naomi, completes the narrative about the final struggle between Romans and Jews during the Bar Kochba Revolt. The book concludes with Hadrian's proclamations. Illustrations abound in this reader, giving students an anchor for understanding the

Author of correspondence: Lynn LiCalsi, E-mail: bolderartcreations@gmail.com

Cite this article: LiCalsi L (2021). Provincia Iudaea: Eliana, Masada, Aelia Capitolina. The Journal of Classics Teaching 22, 68-70. https://doi.org/10.1017/S2058631021000118 narrative. Vocabulary is provided on facing pages so that students can read without the burden of looking up words. Some words appear in the dictionary entry format, whereas others are simply glossed. The reason for this is not to burden students with grammatical details

The dictionary words are words which students should know or learn. The stories are engaging, informative, and (I hope) thoughtprovoking, and are designed to arouse students' interest in history, leading to class discussions about customs, religion, language and life. The stories are written in Latin and include some Hebrew and Greek, thus reflecting multi-cultural first-century Judaea.

This project began three years ago. I had attended several Comprehensible Input (CI) workshops and liked the idea of incorporating CI ideas into my lessons. It was lots of fun, but it stopped there. Then I found that there were many new, good, Latin paperback readers for students to enjoy. These were fun and instructional, but not meaningful in the way that I think grabs students' attention and inspires them to know more. It was then that I came up with an idea for my book. I wanted students to read something that I hoped would prompt real-world discussions. I wanted students who didn't celebrate Christmas and sing Latin Christmas Carols by heart to feel more included and have the opportunity to share their cultural background with their peers. We don't have much diversity in Boulder, Colorado, where I live, but I was and am keenly aware that there is a need to hear more voices. Students sampled my work over the course of three years. The story changed again and again as I made decisions about what was going to happen and why. In the end I completed a narrative that leant itself to relevant modern discussions about different kinds of people living together.

I did most of the illustrations myself but featured students' work as well. I thought that seeing Romans from a different perspective would be of great value. What was it like to live under Roman rule when your culture is not their culture? I finished writing my book and with great help from excellent editors, it was ready to go. Yes, Provincia Iudaea is a fictional story set in the first century CE. It is not meant to be a history book. The focus is on young Jewish girls and their experiences. Over the course of my 30-year plus Latin teaching career, I have learned that keeping up with the times is mere survival, but embracing changing times, questioning your methods, experimenting with new ideas, failing sometimes, and learning from mistakes, not only hones your skills but also keeps customers coming. In this 21st century, Latin has not lost its value because it is a powerfully rich language; however, that fact is not enough to keep Latin alive. I believe that Latin has survived and flourished because Latin teachers are willing to grow and change. For me, teaching has always been a dance. Teachers and students 
are partners. Small adjustments in my teaching methods have kept students on the dance floor. How discouraging it would be to dance with a know-it-all teacher, who delights in him/herself and steps on

\section{Cēna et Post Cēnam}

Līvia et Eliāna trīclīnium intrant.

Est magna mēnsa in mediīs trībus lectīs.

Līvia explicat līberōs in trīclīniō cum parentibus et familiāribus et hospitibus cēnāre.

Mox multī hospitēs adveniunt.

Aliī hospitēs sunt obēsī, aliī gracilēs.

Aliī sunt venustī et aliī invenustī.

Pater Līiae, nōmine Līius, eōs excipit.

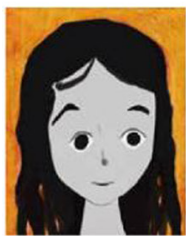

Māter Līviae, nōmine Semprōnia, nōn cēnābit, quod est aegra.

Semprōnia in suō cubiculō dormit.

Cēna est splendida, sed Eliāna animadvertāvit nūllās precēs ante cēnam dictās esse.
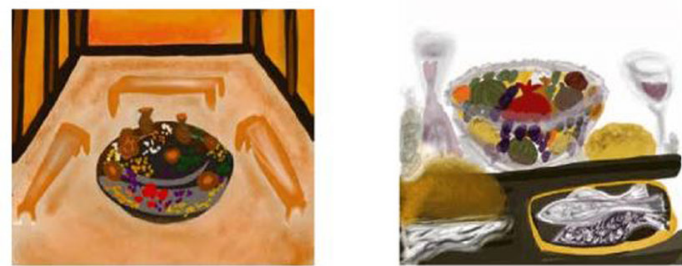

94

Figure 2. Extract from Eliana, pages 94-95

- Capitulum II Iter -

Cum plaustra ad quadrivium advēnērunt, Eliāna inquit, "Cūr dēsistimus?"

Joshua dīxit, "Hīc dormiēmus."

Eliāna et māter ē plaustrō dēscendērunt et humī storeās posuērunt.

Leah et Joshua et infāns procul prope alterum plaustrum storeās posuērunt.

Leah et Joshua diū susurrābant.

Disputābant. Eliāna et Rebecca eōrum vōcēs, nōn verba audīvērunt.

Eliāna et sua māter prope saxum ingēns storēās posuerant.

Leah et Joshua continenter susurrābant.

Ante dormivērunt, Leah ad eās vēnit.

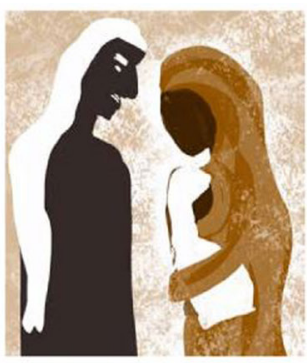

160

Figure 3. Extract from Masada, pages 160-161 everyone's toes, except for those of the very elite, few, and naturally talented students. I learned early on to make Latin accessible to all. My book, Provincia Iudaea, is an example of that dance.

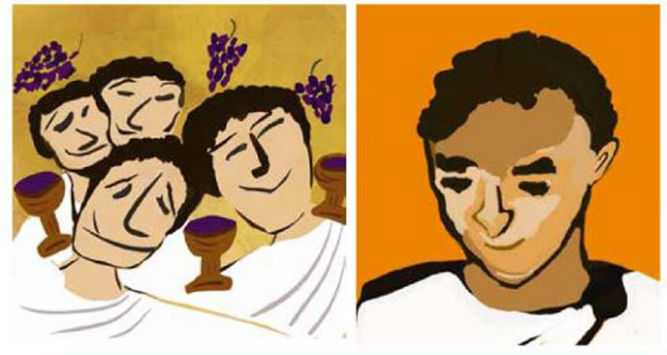

in mediīs trībus in the middle of three

lectus, -i m. bed, couch

liberī, liberōrum $\mathrm{m}$. children

familiāribus relatives

cēnăre to dine

hospes, hospitis, $\mathrm{m}$. guest

adveniunt arrive

aliī...alii Some...Others...

gracilis, e slender

excipit welcomes

eōs them (acc. pl.)

venustus-a-um charming, graceful

invenustus-a-um crude, uncharming

nōn cēnābit will not dine

aeger-aegra-aegrum sick

suus-a-um her own

animadvertāvit noticed that...nūllās precēs no prayers (acc. pl.)

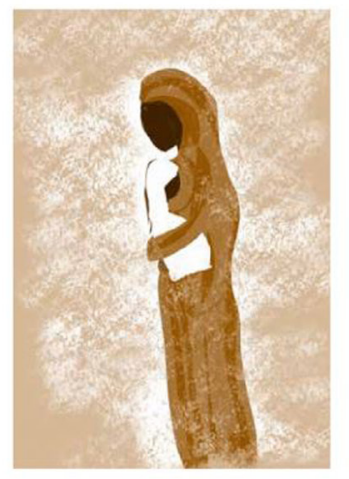

quadrivium, în.

a place where four roads meet,

crossroads

advēnērunt arrived

dēsistimus stopping

dormiēmus will sleep

Hīc here

humī on the ground

eãrum their

storeầs straw mats

procul at a distance

prope near + acc.

alterum another

posuerant had placed/put

diū for a long time

susurrăbant were whispering

Disputābant they were arguing

vōcēs voices

saxum rock

ingềns enormous

procul at a distance

continenter continuously

ad eãs toward them 


\section{Beitar}

In hōc oppidō Naomi novam amīcam Iūdaeam invenit.

Nōmen amīcae est Miriam.

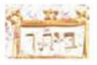

Miriam dīcit, "Naomi, Beitar placidum vidētur, sed aliquandō

Rōmānī veniunt, arma postulant aut pecūniam rapiunt, aut peius,

fēminās et puellās aut infantēs capiunt. Eīs servīs ūtī sunt.

Haec est vēritās - in illō oppidō est maximus terror,

et ille terror semper in aere usque pendet et nōbīs minātur."

Naomi, autem, oppidum placidum observat.

Naomi multam puchritūdinem videt.

Hominēs sunt laetī et contentī videntur.

Naomi mīrātur, "Quōmodo est idem oppidum tam varium hominibus?

Hīs hominibus vīta in oppidō est mīrābilis,

sed illīs vīta in eōdem oppidō est miserābilis."

Miriam eī explicat, "In hōc oppidō aliī Iūdaeī sunt auxiliō Rōmānīs,

sed nōn omnēs."

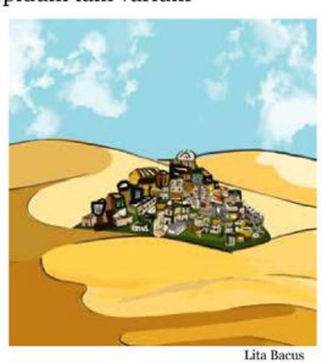

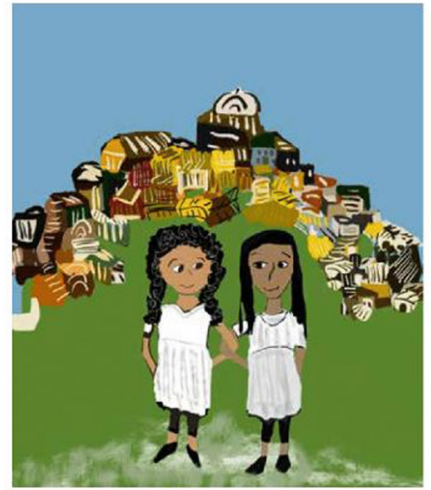

"y)

invenit finds

placidus-a-um peaceful

vidētur seems

aliquandō sometimes

arma postulant they demand weapons

rapiant seize

aut peius or worse

Eîs servīs ūtī sunt they use them as

slaves

Haec est vērităs This is the truth

in aere in the air

\section{口า7\%}

usque continuously

pendet hangs

minātur threatens

videntur seem

tam varium so different

His hominibus For these people

illis for those

eōdem same

auxiliō Rōmānīs a help to the

Romans

double dative

omnēs all

Figure 4. Extract from Aelia Capitolina, pages 262-263 